Published with Open Access at Journal BiNET

Vol. 07, Issue 02: 638-646

Journal of Bioscience and Agriculture Research

Home page: www.journalbinet.com/jbar-journal.html

\title{
In vitro regeneration potentiality of some Brassica genotypes
}

\author{
S. C. Das ${ }^{a}$, L. Hassan ${ }^{a}$, M. A. Quddus ${ }^{a}$ and B. P. Ray ${ }^{b}$
}

aDept. of Genetics and Plant Breeding, Bangladesh Agricultural University, Mymensingh

${ }^{b}$ Biotechnology Division, Bangladesh Institute of Nuclear Agriculture, Mymensingh, Bangladesh

$\bowtie$ sumancdas@yahoo.com (Das, S. C.), Published: 31 March 2016

\begin{abstract}
Ten genotypes of Brassica, from three different groups of species, namely Tori-7, Kallyania, Sampad, Sonali (each from Brassica campestris), BARI sarisa-7, BARI sarisa-8 and MM-20-3 (each from Brassica napus), Rai-5, Shambal and Daulat (each from Brassica juncea) were selected to observe their in vitro regeneration potentiality using stem segment as the explants. Investigations on regeneration of these ten genotypes were accomplished with callus induction, maintenance of calli, organogenesis and finally plantlet regeneration and subsequent their establishment in the field condition. Among the varieties, BARI sarisa-8 showed the highest response in all aspects. Callus induction was highest in BARI sarisa-8 (99.60\%) and lowest in Sonali (92.40\%). Time required for shoot initiation was minimum in BARI sarisa-8 (21.12days) while it was maximum in Kallyania (25.12 days). Number of shoots per callus was highest in BARI sarisa-8 (2.502) and lowest in MM-20-3 (1.208). Number of rooted shoots was highest in BARI sarisa-8 (55.56\%). Survival rate of regenerated plantlets was highest in BARI sarisa-8 (80.00\% in pot and $75.00 \%$ in soil) while the same was lowest in Kallyania (61.11\% in pot) and in BARI sarisa-7 (30.00\% in soil).
\end{abstract}

Key Word: In vitro regeneration, Brassica, Hypocotyl segment, Genotypes and Potentiality

Please cite this article as: Das, S. C., Hassan, L., Quddus, M. A \& Ray, B. P. (2016). In vitro regeneration potentiality of some Brassica genotypes. Journal of Bioscience and Agriculture Research, 07(02), 638-646.

This article is distributed under terms of a Creative Common Attribution 4.0 International License.

\section{Introduction}

Oil seed Brassica (rapeseed and mustard) is one of the most important sources of edible vegetable oil, industrial used oil and protein-rich product in the world. Its oil has many advantages, while many of the other edible oils lack one of the two essential fatty acids; rapeseed-mustard provides both the essential fatty acids to the human body- linoleic acid and linolenic acid. Significantly, it contains the lowest amount of saturated fatty acids among the vegetable oils, higher amounts of which from deposits in the arteries, causing attendant heart problems. The de-oiled cake serves as animal feed and fertilizer. It is a good source of protein with well-balanced amino acids and minerals (Pachauri, 2001). Brassica ranks third after soybean and palm oil in the global production. About $13.2 \%$ of the world's edible oil supply comes from this crop (Downey and Robbelen, 1989). It is the top ranking oilseed crop of Bangladesh. It covers the highest acreage, which is $61.2 \%$ of the total oilseeds acreage of Bangladesh and $52.6 \%$ of the total production (BBS, 1999). 
The productivity and quality of these crops are affected by various biotic and abiotic stresses. Biotic stresses that reduce the production of crops include infestation by insects, damage due to bacterial and fungal pathogens. In Bangladesh rapeseed and mustard suffers from 14 different diseases. Among these leaf blight, downy mildew and parasitic plant are important. The most important disease of Brassica in Bangladesh is leaf blight disease, caused by Alternariabrassicae (Ahmed, 1952). The disease causes leaf blight, pod blight and seed abnormalities (Meah, 1986). Crop loss between 30 and 100\% due to this disease has been reported (Meah et al., 1988). The most important pest of this crop is aphid (Lipaphiserysimi).

Although a number of new varieties have been released from different research institutes of Bangladesh, none has come up to the expectation of breeders, because the released varieties are not resistant to above diseases and pests. Plant breeders in the past for several decades have used interspecific hybridization to transfer genes between species. Cross incompatibility barriers severely limit the possibility of gene transfer between species, although some of the Brassica species can be easily crossed conventionally (Puddephat et al., 1996). Conventional breeding programmes alone were not successful enough in Brassica due to high degree of segregation upon cross pollination and unavailability of suitable germplasm. Besides, conventional breeding is labour and resource intensive and time consuming; it takes eight to ten generations to develop a new variety (Cardoza and Stewart, 2006). It is now realized that regeneration of plants from tissue culture is an important and essential component of plant breeding and biotechnological research. The totipotency of the cell or tissue open up several new contingencies in plant breeding progress that provides gene manipulation and selection of desirable character. On the other hand, in recent years genetic transformation technique has been used to develop biotic and abiotic stress tolerant crop plants. However, before embarking upon such a programme on genetic transformation it is necessary to establish in vitro plant regeneration system of that particular plant. Many efforts have been undertaken to establish a suitable in vitro regeneration protocol for Brassica. It has consistently proved to be one of the most recalcitrant members of the Brassicaceae in tissue culture (Hachey et al., 1991). Due to the recalcitrant nature of Brassica tissue in vitro, it eluded any notable progress in his regard for a long time. However, there are reports on the use of in vitro techniques like organogenesis and somatic embryogenesis for the regenerationof different Brassica spp. (Antonio et al., 1987, Ono et al., 1994, Khan et al., 2002). Considering all the issues, the objective of the present study was to investigate the regeneration potentiality of ten number of locally available oilseed Brassica genotypes.

\section{Materials and Methods}

\section{Plant materials}

The experiment was conducted in the Tissue Culture Laboratory of the Department of Genetics and Plant Breeding, Bangladesh Agricultural University, Mymensingh, Bangladesh during the period from January 2003 to April 2004. Ten different genotypes of Brassica such as, Tori-7, Kallyania, Sampad, Sonali, BARI sarisa-7, BARI sarisa-8, MM-20-3, Rai-5, Shambal and Daulat were used in the present investigation to study different parameters associated with plant regeneration.

\begin{tabular}{|c|c|}
\hline Stage & Media used \\
\hline Seed germination & $\begin{array}{l}\text { Half strength MS (Murashige and Skoog, 1962) medium } \\
\text { supplemented with } 20 \mathrm{gmL}^{-1} \text { sucrose }\end{array}$ \\
\hline $\begin{array}{l}\text { Callus induction and shoot } \\
\text { differentiation }\end{array}$ & $\begin{array}{l}\text { MS medium supplemented with } 3 \mathrm{mgL}^{-1} \mathrm{BAP}, 0.1 \mathrm{mgL}^{-1} \\
\mathrm{NAA} \text { and } 2 \mathrm{mgL}^{-1} \mathrm{AgNO}_{3}\end{array}$ \\
\hline $\begin{array}{l}\text { Callus induction and shoot } \\
\text { differentiation }\end{array}$ & $\begin{array}{l}\text { MS medium supplemented with } 3 \mathrm{mgL}^{-1} \mathrm{BAP}, 0.1 \mathrm{mgL}^{-1} \\
\mathrm{NAA} \text { and } 2 \mathrm{mgL}^{-1} \mathrm{AgNO}_{3}\end{array}$ \\
\hline Root initiation & $\begin{array}{l}\text { Half strength MS medium supplemented with } 0.5 \mathrm{mgL}^{-1} \\
\text { NAA }\end{array}$ \\
\hline $\begin{array}{l}\text { Transplanting of plantlets from culture } \\
\text { vessel to pot in growth chamber }\end{array}$ & $\begin{array}{l}\text { Soil containing } 25 \% \text { garden soil }+50 \% \text { sand }+25 \% \\
\text { cowdung }\end{array}$ \\
\hline $\begin{array}{l}\text { Watering the plantlets in the growth } \\
\text { chamber }\end{array}$ & Hoagland's solution \\
\hline $\begin{array}{l}\text { Transplanting of plantlets from growth } \\
\text { chamber's pot to earthen pot }\end{array}$ & $\begin{array}{l}\text { Soil containing } 25 \% \text { garden soil }+50 \% \text { sand }+25 \% \\
\text { cowdung }\end{array}$ \\
\hline
\end{tabular}




\section{The following culture techniques were employed in the present investigation:}

\section{Explant preparation}

The seedlings raised in axenic culture were used as the source of explants. Hypocotyl segments with 5$7 \mathrm{~mm}$ in length were used as explants. Hypocotyl segments from each germinated seedling were cut into 5-7 $\mathrm{mm}$ pieces using sterilized surgical blades. Ten pieces of stem segments were arranged horizontally on each petridish and gently pressed into the surface of the sterilized culture medium in combinations with growth regulators like BAP, $\mathrm{NAA}$ and $\mathrm{AgNO}_{3}$. The culture plates containing explants were placed under fluorescent light in a room with controlled temperature $\left(22 \pm 2^{\circ} \mathrm{c}\right)$ using $16 \mathrm{hrs}$. photoperiod. The petridishes were checked daily to note the response and the development of contamination. Callus were initiated six days after inoculation and after two weeks inoculated explants were transferred onto fresh medium.

\section{Subculture or transfer}

Two weeks after inoculation of explants, when the calli attained convenient size, they were removed aseptically from the petridish on a sterilized glass plate inside the laminar airflow cabinet and were placed again on freshly prepared sterilized medium containing appropriate hormonal supplements for shoot induction form the cells. The subculturing media used in present investigation were MS containing different concentrations of BAP, $\mathrm{NAA}$ and $\mathrm{AgNO}_{3}$. The subcultured petridishes were again incubated at $22 \pm 2{ }^{\circ} \mathrm{C}$ with $16 \mathrm{hrs}$. photoperiod. After shoot initiation, more light intensity was used for shoot elongation. The culture vessels showing signs of contamination were discarded. Repeated subcultures were done at and interval of fifteen days and incubated under the same temperature as mentioned previously for maintenance of calli and organogenesis.

\section{Rooting}

The subcultured calli continued to proliferate and differentiated into shoots. When these shoots grew about $2-3 \mathrm{~cm}$ in length, they were rescued aseptically from the cultured petridishes and were separated from each other and again cultured individually on vials or conical flasks with freshly prepared root induction medium to induce root. The vials or conical flasks containing plantlets were incubated at $22 \pm 2^{\circ} \mathrm{C}$ with $16 \mathrm{hrs}$. photoperiod. Day to day observations were carried out to note the responses.

To investigate the responses of different varieties to callus induction and plantlet regeneration, data were collected from the different parameters like Callus induction, Days of callus initiation, percentage of callus induction, Size of callus, Colour of callus, Nature of callus, Abundance of callus, Weight of callus, Days to shoot initiation, Number of callus with shoot (percent shoot regeneration), Number of shoots per callus (Average number of shoots per callus), Total number of shoots per petridish, Number of shoots with roots, and Percentage of plant establishment.The data for the mentioned parameters were statistically analyzed wherever applicable. The analyses of variances for different parameters were performed and means were compared by the Duncan's Multiple Range Test (DMRT).

\section{Results and Discussion}

\section{Callus induction}

Hypocotyl segments started callus induction after six days of incubation and it took about 8 days for completion. The percentage of callus induction was highest in Daulat (99.6) followed by MM-20-3 (98). Callus induction was lowest (92.4\%) in Sonali (Figure01). The mean values of genotypes due to callus inducing characters like days to callus initiation, callusing per petridish, size of callus, colour of callus, nature of callus, weight of callus and abundance of callus were found statistically significant. Sampad started callus initiation early (6.84 days) in comparison to other genotypes such as Rai-5 (7 days), Tori-7 (7.04 days), BARI sarisa-8 (7.08 days) and BARI sarisa-7 (7.12 days). Sonali was delayed (7.4 days) in callus initiation. Daulat showed highest (9.96) callusing/petridish (Plate 1) followed by MM20-3 (9.8), and Rai-5, Tori-7, Kallyania, BARI sarisa-7 and Sampad (9.72 in each genotype). Callusing/petridish was lowest (9.24) in Sonali. Callus size was highest $(0.496 \mathrm{~cm})$ in BARI sarisa-8 followed by Rai-5 $(0.484 \mathrm{~cm})$ and MM-20-3 $(0.477 \mathrm{~cm})$, and smallest $(0.373 \mathrm{~cm})$ in Sampad. MM-20-3 showed greenish (2.91) callus followed by Sonali (2.82) and BARI sarisa-8 (2.80) whereas Rai-5 and 
Daulat showed cream coloured (2.21 and 2.23, respectively) callus. MM-20-3 showed compact natured callus (2.938) followed by BARI sarisa-8 (2.922) and BARI sarisa-7 (2.884). Friable callus was found in Rai-5 (2.228) and Daulat (2.108). Sonali, Tori-7 and Shambal showed mostly friable to compact natured callus. Callus abundance was highest in MM-20-3 (2.80) followed by BARI sarisa-8 (2.752). Sampad showed poor performance (2.283) in callus abundance (Table 01).

Callus weight was highest (0.331 g) in BARI sarisa-8 followed by BARI sarisa-7 (0.294g), MM-20-3 $(0.292 \mathrm{~g})$ and Shambal $(0.289 \mathrm{~g})$. Callus weight was lowest $(0.209 \mathrm{~g})$ in Sampad. From the above findings, it was found that BARI sarisa-8 showed comparatively better potentiality in callus growth than other genotypes. This finding confirmed the findings of Javed and Hassan (1992).

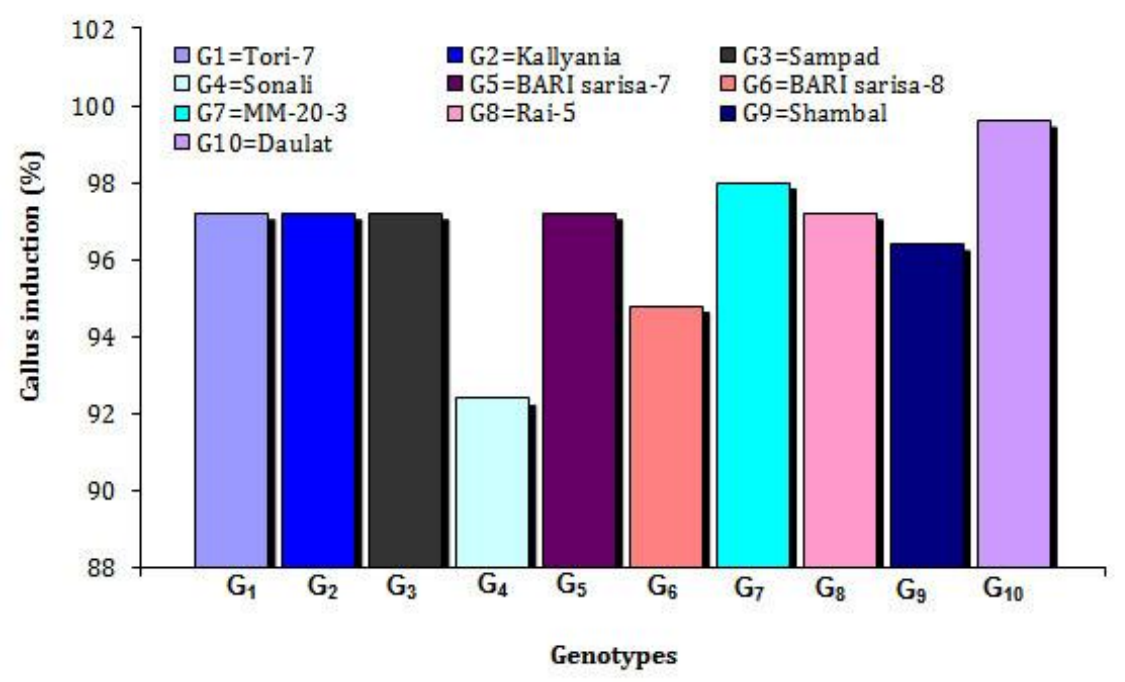

Fig. 1. Response of ten genotypes of Brassicatowards callus induction

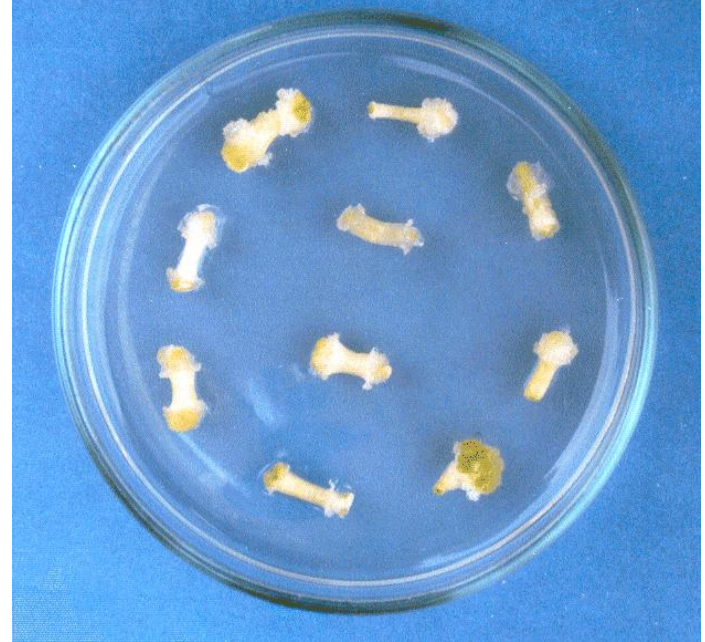

Plate 01. Callus initiation of Daulat on callus induction medium.

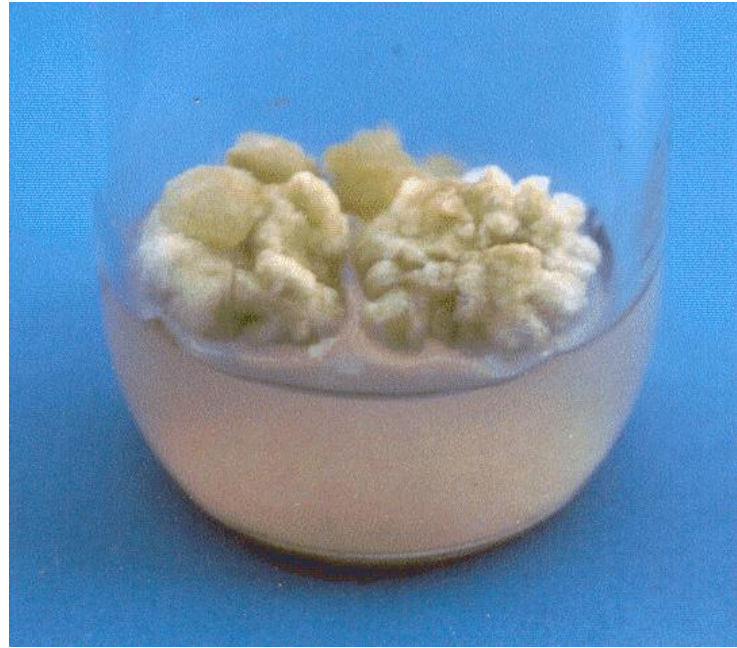

Plate 02. Proliferated callus of BARI sarisa-8. 
Table 01. Performance of the genotypes on different callus characters of Brassica

\begin{tabular}{|c|c|c|c|c|c|c|c|}
\hline \multirow[b]{2}{*}{ Genotypes } & \multicolumn{7}{|c|}{ Characteristics of callus } \\
\hline & 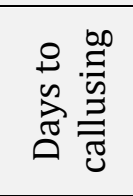 & 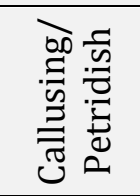 & 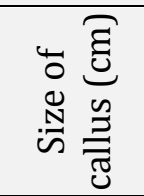 & $\begin{array}{l}\text { पั0 } \\
\vdots \\
\vdots \\
0\end{array}$ & 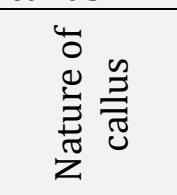 & 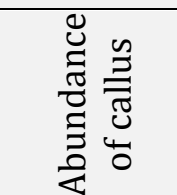 & 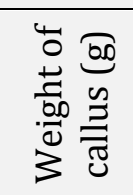 \\
\hline Tori-7 & $7.04 \mathrm{bc}$ & $9.72 \mathrm{ab}$ & $0.423 \mathrm{e}$ & $2.752 \mathrm{bcd}$ & $2.794 \mathrm{cde}$ & $2.534 \mathrm{bcd}$ & $0.277 \mathrm{c}$ \\
\hline Kallyania & $7.16 \mathrm{~b}$ & $9.72 a b$ & $0.427 \mathrm{e}$ & $2.716 \mathrm{~cd}$ & $2.838 \mathrm{bcd}$ & $2.599 \mathrm{~b}$ & $0.254 \mathrm{~d}$ \\
\hline Sampad & $6.84 \mathrm{c}$ & $9.72 \mathrm{ab}$ & $0.373 \mathrm{i}$ & $2.753 \mathrm{bcd}$ & $2.801 \mathrm{cde}$ & $2.283 \mathrm{e}$ & $0.209 \mathrm{f}$ \\
\hline Sonali & $7.408 \mathrm{a}$ & $9.24 \mathrm{c}$ & $0.395 \mathrm{~h}$ & $2.823 \mathrm{~b}$ & $2.765 \mathrm{de}$ & $2.444 \mathrm{~d}$ & $0.222 \mathrm{e}$ \\
\hline BARI sarisa-7 & $7.12 \mathrm{~b}$ & $9.72 a b$ & $0.405 \mathrm{~g}$ & $2.665 \mathrm{~d}$ & $2.884 \mathrm{abc}$ & $2.579 \mathrm{bc}$ & $0.294 \mathrm{~b}$ \\
\hline BARI sarisa-8 & $7.08 \mathrm{~b}$ & $9.48 \mathrm{bc}$ & $0.496 \mathrm{a}$ & $2.800 \mathrm{bc}$ & $2.922 \mathrm{ab}$ & $2.752 \mathrm{a}$ & $0.331 \mathrm{a}$ \\
\hline MM-20-3 & $7.20 \mathrm{~b}$ & $9.80 a b$ & $0.477 \mathrm{c}$ & $2.916 \mathrm{a}$ & $2.938 \mathrm{a}$ & $2.800 \mathrm{a}$ & $0.292 \mathrm{~b}$ \\
\hline Rai-5 & $7.00 \mathrm{bc}$ & $9.72 a b$ & $0.484 \mathrm{~b}$ & $2.213 \mathrm{e}$ & $2.228 \mathrm{f}$ & $2.489 \mathrm{~cd}$ & $0.288 \mathrm{~b}$ \\
\hline Shambal & $7.16 \mathrm{~b}$ & $9.64 \mathrm{ab}$ & $0.435 \mathrm{~d}$ & $2.743 \mathrm{bcd}$ & $2.727 \mathrm{e}$ & $2.497 \mathrm{~cd}$ & $0.289 \mathrm{~b}$ \\
\hline Daulat & $7.12 \mathrm{~b}$ & $9.96 \mathrm{a}$ & $0.416 \mathrm{f}$ & $2.236 \mathrm{e}$ & $2.108 \mathrm{~g}$ & $2.542 \mathrm{bcd}$ & $0.221 \mathrm{e}$ \\
\hline
\end{tabular}

Different genotypes showed wide variations in callus proliferation (Figure02). Callus proliferation was highest (68.8\%) in BARI sarisa-8 (Plate 02) followed by Rai-5 and MM-20-3, lowest (44.8\%) in Sonali.

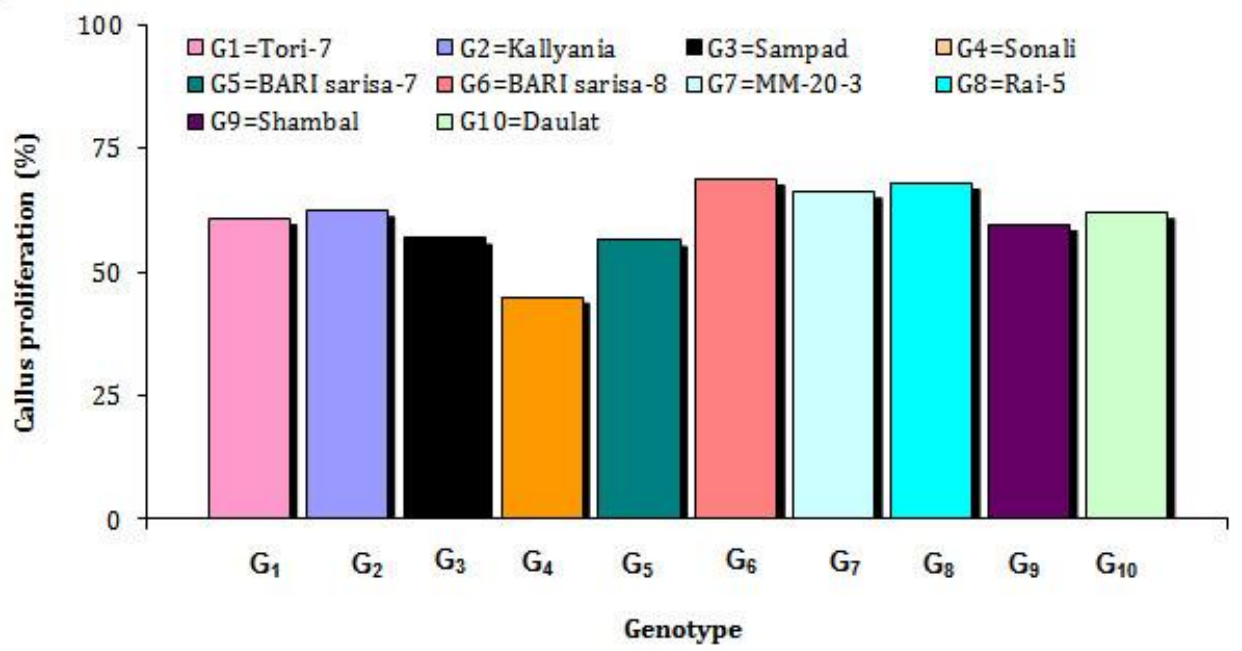

Fig. 2. Response of different genotypes towards callus proliferation

After two to three subcultures, the calli exhibited variation in colour and texture i.e., calli become friable in texture and greenish in colour. The subcultured calli then started regeneration by shoot bud initiation. It was also observed from this study that after third subculture calli showed variation in texture and colour. These findings agreed with the result of Maeda et al. (1981) who reported that after subculturing, the texture of calli altered gradually from compact to friable.

\section{Organogenesis via callus}

The primary objective of any in vitro technique is to establish the explants in culture, resulted in the formation of shoots and subsequently the development of roots for the production of free-living plantlets. It was worth noting that all the genotypes showedvariations in shoot proliferation (Figure03) and shoot regeneration was found highest in Tori-7 (46.4\%) followed by BARI sarisa-8 (41.6\%), Daulat (40.4\%) and BARI sarisa-7 (37.6\%). It was evident from the findings of Tang and Jhou (2001), Du et al. (2000) and Wang et al. (2000) that BAP in higher concentration was the most effective stimulator for shoot regeneration.

Mean values of all the genotypes were found statistically significant for all the characters of shoot regeneration like days required for shoot initiation, number of callus with shoot/petridish, number of shoot/callus and total number of shoots/petridish. The results are presented in the Table 02 . It was observed that among the genotypes tested, days required for shoot initiation was minimum in BARI 
sarisa-8 (21.12 days) followed by BARI sarisa-7 (21.56 days). It was maximum (25.12 days) in Kallyania. Number of callus with shoot/petridish was highest in Tori-7 (4.64) (Plate 03) and lowest in Sonali (2.76). BARI sarisa-8 showed maximum number of shoots/callus (2.502) (Plate 04) followed by Daulat (1.968), BARI sarisa-7 (1.624), Rai-5 (1.440) and MM-20-30 (1.208). Total number of shoots/petridish was highest in BARI sarisa-8 (23.28) followed by Daulat (19.64), Tori-7 (18.92), BARI sarisa-7 (15.84) and Rai-5 (14.08).

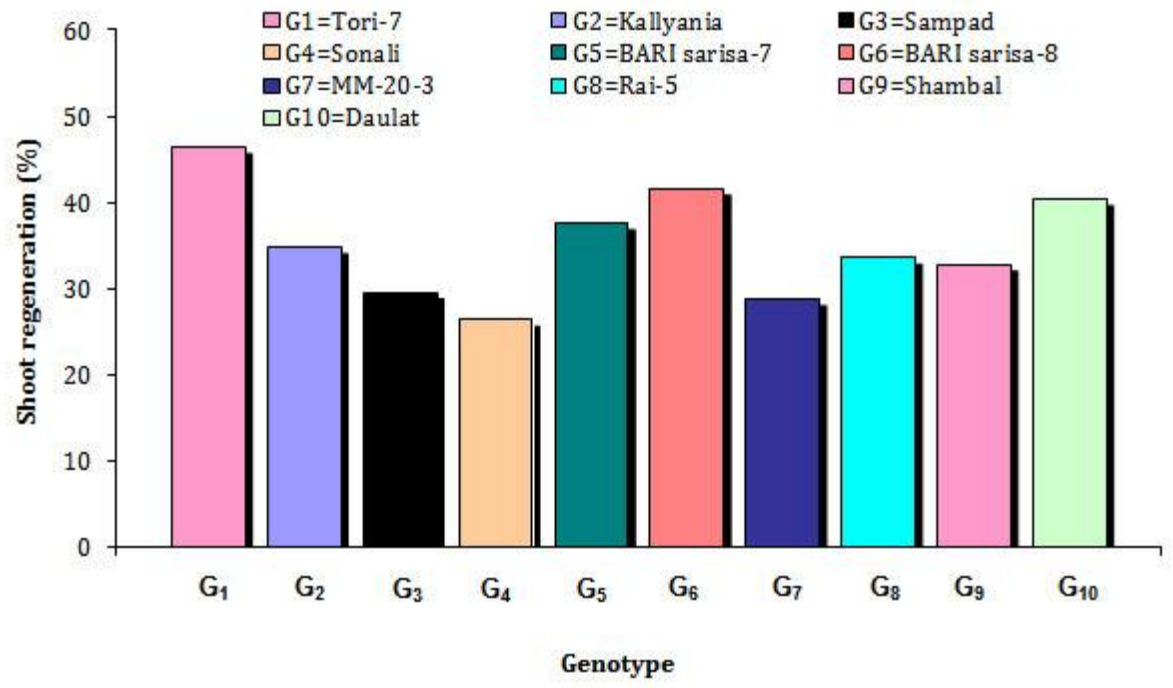

Fig. 3. Response of different genotypes of Brassica towards shoot regeneration

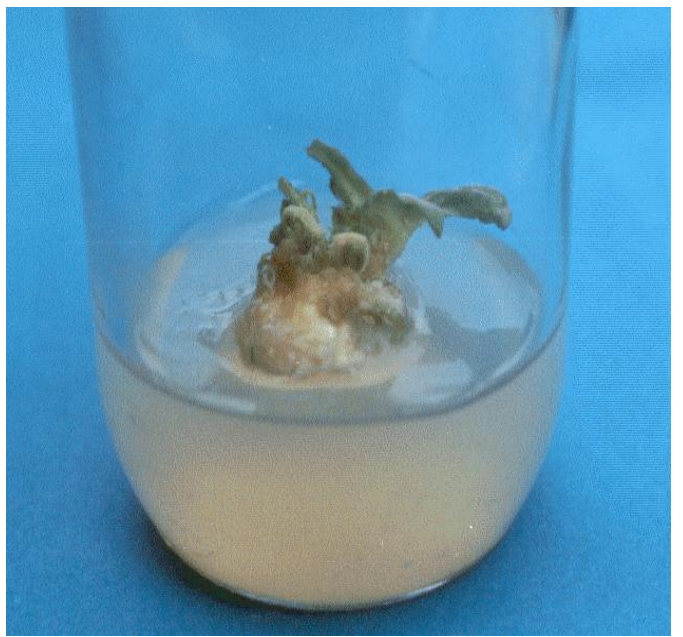

Plate 03. Shoot regeneration from calli of Tori-7 on shoot differentiation medium.

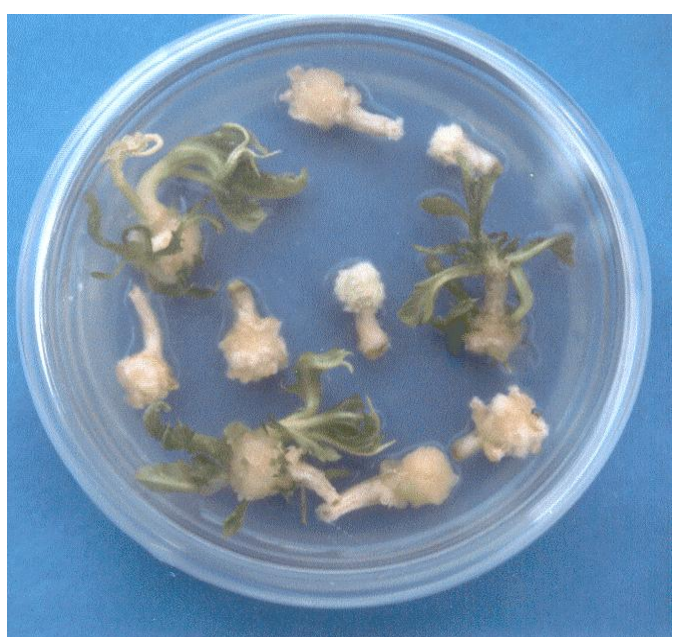

Plate 04. Shoot regeneration of BARI sarisa-8on shoot differentiation medium.

Table 02. Effects of different genotypes of Brassica on different characters of shoot regeneration

\begin{tabular}{ccccc}
\hline \multirow{2}{*}{ Genotype } & \multicolumn{4}{c}{ Characters } \\
\cline { 2 - 5 } & $\begin{array}{c}\text { Days to shoot } \\
\text { initiation }\end{array}$ & $\begin{array}{c}\text { No. of callus with } \\
\text { shoots/petridish }\end{array}$ & $\begin{array}{c}\text { Total no. of } \\
\text { shoots/callus }\end{array}$ & $\begin{array}{c}\text { Total no. of } \\
\text { shoots/petridish }\end{array}$ \\
\hline Tori-7 & $23.16 \mathrm{de}$ & $4.64 \mathrm{a}$ & $1.944 \mathrm{~b}$ & $18.92 \mathrm{~b}$ \\
Kallyania & $25.12 \mathrm{a}$ & $3.48 \mathrm{c}$ & $1.319 \mathrm{de}$ & $12.76 \mathrm{de}$ \\
Sampad & $24.32 \mathrm{~b}$ & $2.96 \mathrm{~d}-\mathrm{f}$ & $1.182 \mathrm{e}$ & $11.48 \mathrm{e}$ \\
Sonali & $23.52 \mathrm{~cd}$ & $2.52 \mathrm{f}$ & $1.330 \mathrm{de}$ & $12.36 \mathrm{de}$ \\
BARI sarisa-7 & $21.56 \mathrm{f}$ & $3.68 \mathrm{bc}$ & $1.624 \mathrm{c}$ & $15.84 \mathrm{c}$ \\
BARI sarisa-8 & $21.12 \mathrm{f}$ & $4.16 \mathrm{~b}$ & $2.502 \mathrm{a}$ & $23.28 \mathrm{a}$ \\
MM-20-3 & $24.00 \mathrm{bc}$ & $2.84 \mathrm{ef}$ & $1.208 \mathrm{de}$ & $11.84 \mathrm{e}$ \\
Rai-5 & $22.76 \mathrm{e}$ & $3.36 \mathrm{~cd}$ & $1.440 \mathrm{~cd}$ & $14.08 \mathrm{~cd}$ \\
Shambal & $23.72 \mathrm{c}$ & $3.28 \mathrm{c}-\mathrm{e}$ & $1.213 \mathrm{de}$ & $11.72 \mathrm{~d}$ \\
Daulat & $23.96 \mathrm{bc}$ & $4.04 \mathrm{~b}$ & $1.968 \mathrm{~b}$ & $19.64 \mathrm{~b}$ \\
\hline
\end{tabular}




\section{Regeneration of root}

Shoots regenerated from cultured explants were mostly without of any root needed to establish themselves in the field. In order to induce root formation in the differentiated shoots, they were transferred to half strength MS medium supplemented with $0.5 \mathrm{mgL}-1 \mathrm{NAA}$. Induction of root from regenerated shoots showed wide variations according to genotypes (Table 03). BARI sarisa-8 had the highest percentage (55.56) of rooted shoots (Figure04). BARI sarisa-8 showed highest number of shoots with root (1.667) followed by Tori-7 (1.40), Rai-5 (1.40) and Daulat (1.333). Sampad, Sonali and Shambal failed to produce any root on the regenerated shoot.

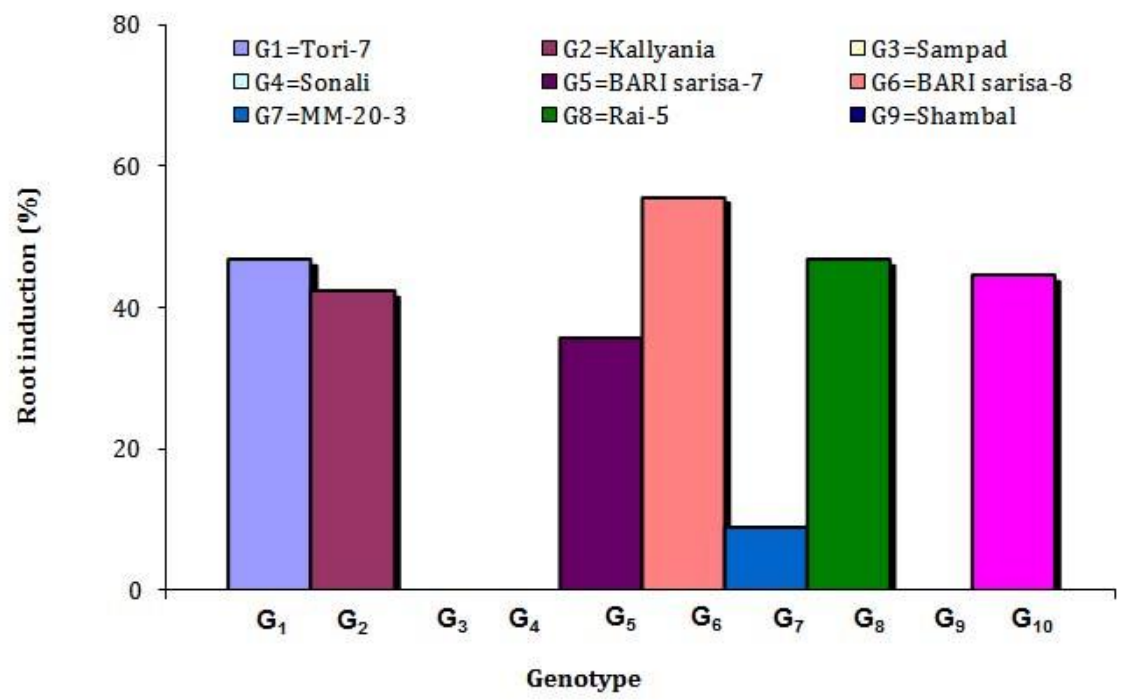

Fig. 4. Response of different genotypes towards root induction

Table 03. Effects of different genotypes of Brassica on number of shoots with root

\begin{tabular}{cc}
\hline Genotypes & Number of shoot with root \\
\hline Tori-7 & $1.400 \mathrm{ab}$ \\
Kallyania & $1.267 \mathrm{~b}$ \\
Sampad & $0.000 \mathrm{c}$ \\
Sonali & $0.000 \mathrm{c}$ \\
BARI sarisa-7 & $1.067 \mathrm{~b}$ \\
BARI sarisa-8 & $1.667 \mathrm{a}$ \\
MM-20-3 & $0.267 \mathrm{c}$ \\
Rai-5 & $1.400 \mathrm{ab}$ \\
Shambal & $0.000 \mathrm{c}$ \\
Daulat & $1.333 \mathrm{ab}$ \\
\hline
\end{tabular}

\section{Establishment of plantlets}

The small plantlets, after sufficient development in root system, were taken out from the culture vessels without causing any damage to roots. Excess media adhered around the roots was washed off by running tap water to prevent microbial infection. The plantlets then transplanted into plastic pots containing sterile soil, sand and cowdung in a 1: 2: 1 ratio. The pots were covered with clear polybag to maintain high humidity conditions (Plate 05 ) and kept in the growth chamber for proper hardening (Plate 06). Gradually the plantlets were adapted to the soil. The survival rate of the plantlets of BARI sarisa-8, Tori-7, Rai-5, Daulat, Kallyania and BARI sarisa-7 were $80,75,76.19,70,61.11,75 \%$ in the pots, and 75, 66.67, 66.67, 60, 50, 30\% in the soil, respectively (Table 04). Rai-5 and BARI sarisa-8 were flowered in the field condition (Plate 07). 
Table 04. Survival rate of regenerants from six genotypes of Brassica after transfer to soil

\begin{tabular}{c|cccc}
\hline $\begin{array}{c}\text { Planting } \\
\text { condition }\end{array}$ & Name of genotype & $\begin{array}{c}\text { No. of plantlets } \\
\text { transplanted }\end{array}$ & $\begin{array}{c}\text { No. of plants } \\
\text { survived }\end{array}$ & $\begin{array}{c}\text { Survival rate } \\
(\%)\end{array}$ \\
\hline \multirow{5}{*}{ In pot } & Tori-7 & 20 & 15 & 75 \\
& Kallyania & 18 & 11 & 61.11 \\
& BARI sarisa-7 & 16 & 12 & 75 \\
& BARI sarisa-8 & 25 & 20 & 80 \\
& Rai-5 & 21 & 16 & 76.19 \\
& Daulat & 20 & 14 & 70 \\
\hline \multirow{5}{*}{ In soil } & Tori-7 & 15 & 10 & 66.67 \\
& Kallyania & 10 & 5 & 30 \\
& BARI sarisa-7 & 10 & 3 & 75 \\
& BARI sarisa-8 & 20 & 15 & 66.67 \\
\cline { 2 - 5 } & Rai-5 & 12 & 8 & 60 \\
\cline { 2 - 5 } & Daulat & 10 & 6 & \\
\hline
\end{tabular}

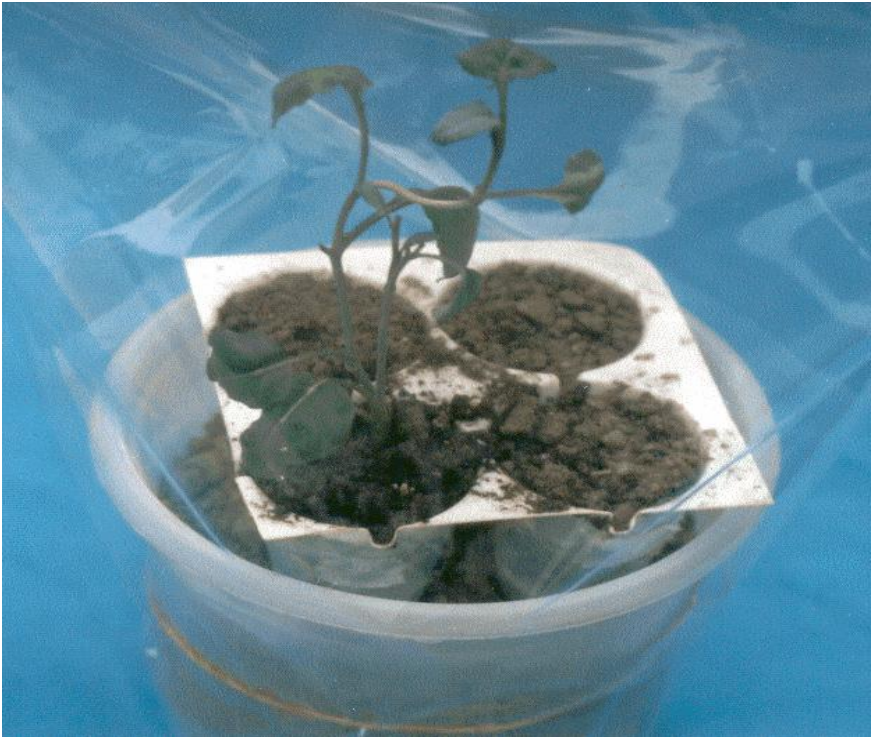

Plate 05. Regenerated plantlet of Tori-7 in plastic pot covered with polythene bag

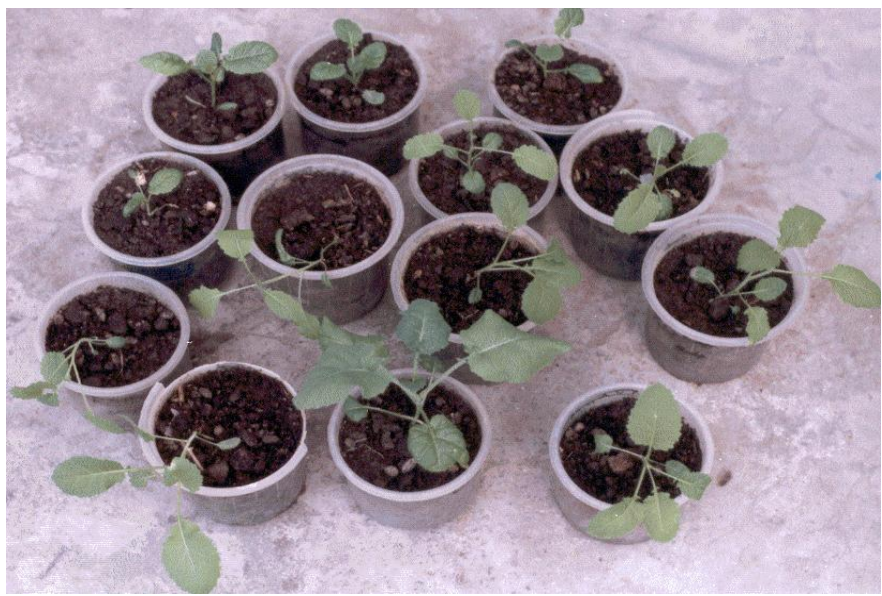

Plate 06. Regenerated plants of Brassica genotypes kept in growth chamber for hardening

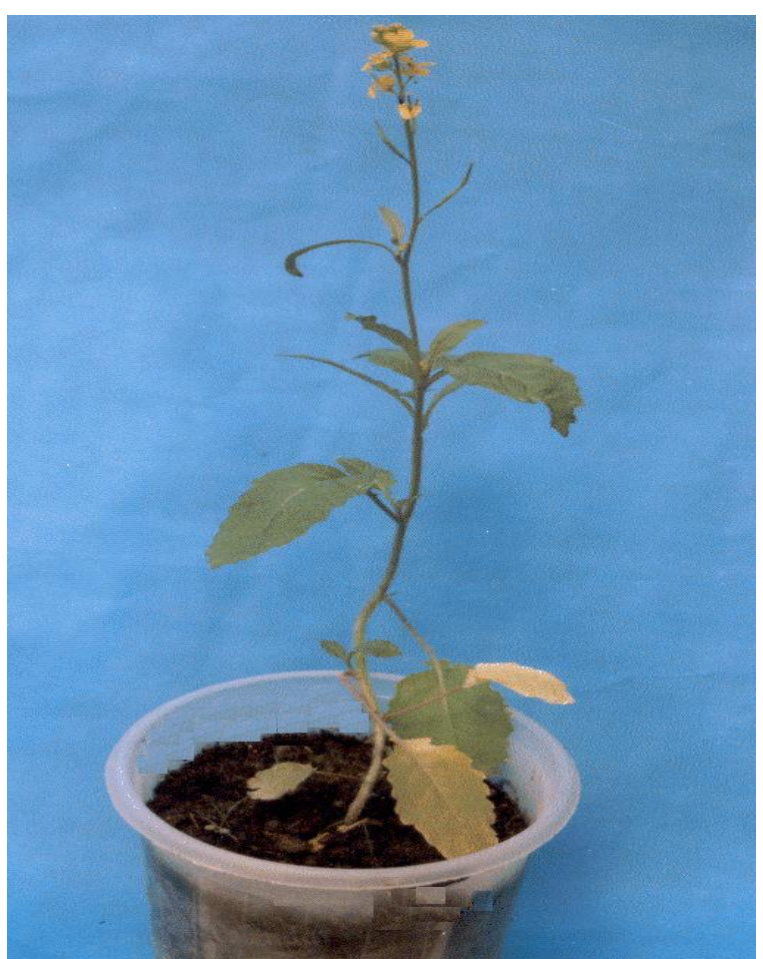

Plate 07. Flowering stage of a regenerated plant of Rai-5 


\section{Conclusion}

We investigated in vitro regeneration potentiality of ten Brassica genotypes using hypocotyl segment as the explant. The genotypes showing better potentiality coupled with higher survival rate onto soil condition may be used for advanced studies specially for transfer of desirable genes through genetic engineering.

\section{References}

[1]. Ahmed, Q. A. (1952). Fungi of East Bengal. Pak. J. For., 2, 91-115.

[2]. Antonio, B. A., Namai, H. \& Kikuchi, F. (1987). Tissue culture ability of vegetative organs from different cultivars of Brassica. SABRAO Journal, 19(2), 73-79.

[3]. BBS. (1999). Statistical Pocket Book of Bangladesh. Bangladesh Bureau of Statistics. Statistics Division, Ministry of planning, Govt. of the People,s Republic of Bangladesh. p. 145.

[4]. Cardoza, V. \& Stewart, N. C. (2006). Canola (Brassica napus L.). Methods Mol. Biol. (ed. Wang, K.). Human Press Inc., Totowa, New Jersey. 343, 257-266. http://dx.doi.org/10.1385/1-59745-130-4:257

[5]. Downey, R. K. \& Robbelen, G. (1989). Brassica species: Oil crops of the world, their breeding and utilization. Mc Graw Hill Publishing Co. New York. pp. 339-374.

[6]. Du, H., Zhuang, D. H. \& Hunang, W. H. (2000). Stimulation effect of silver nitrate on shoot regeneration in cotyledon tissue culture of Brassica campestris. Journal of Tropical and Subtropical Botany, 8(2), 109-112.

[7]. Hachey, J. E., Sharma, K. K. \& Moloney, M. M. (1991). Efficient shoot regeneration of Brassica campestris using cotyledon explants cultured in vitro. Plant Cell Rep,. 9 (100), 549-554. http://dx.doi.org/10.1007/bf00232329

[8]. Javed, M. A. \& Hassan, S. (1992). Callusing and regeneration response of cotyledon explants of some rapeseed genotypes. Sarhad Journal of Agriculture,. 8(3), 329-334.

[9]. Khan, M. R., Rashid, H. \& Quraishi, A. (2002). Effect of various growth regulators on callus formation and regeneration in Brassica napus cv. Oscar. Pak. J. Biol. Sci., 5, 693-695. http://dx.doi.org/10.3923/pjbs.2002.693.695

[10]. Maeda, E., Inoue, M. \& Chen, M. H. (1981). Regulatory mechanism of shoot formation in rice callus. In: A. N. Rao (ed.). Proc. COSTED. Symp. on Tissue Culture of Economically Important Plants. Singapore. pp. 1-6.

[11]. Meah, M. B. (1986). Management of diseases of oilseeds; mustard, groundnut, sesame. In: $B A U$ Research Progress. Workshop held on 4-5 October, 1986. 1,82-100.

[12]. Meah, M. B., Howlider, M. A. R. \& Alam, M. K. (1988). Effect of fungicide spray at different time and frequencies on Alternaria blight of mustard. Thai. J. Agric. Sci., 21, 101-107.

[13]. Murashige, T. \& Skoog, F. (1962). A revised medium for rapid growth and bioassay with tobacco tissue culture. Physiol. Plant., 15, 473-497. http://dx.doi.org/10.1111/j.1399-3054.1962.tb08052.x

[14]. Ono, Y., Takahata, Y. \& Kaizuma, N. (1994). Effect of genotype on shoot regeneration from cotyledonary explants of rapeseed (Brassica napus) . Plant Cell Rep., 14(1), 13-17. http://dx.doi.org/10.1007/BF00233290

[15]. Pachauri, R. K. (2001). Significance of oilseed research in India. TERIvision, India. 37: 2.

[16]. Puddephat, I. J., Riggs, T. J. \& Fenning, T. M. (1996). Transformation of Brassica oleracea L.: a critical review. Mol. Breed, 2, 185-210. http://dx.doi.org/10.1007/BF00564197

[17]. Tang, G. X. \& Jhou, W. J. (2001). Studies on the enhancement of plant regeneration frequency in Brassica napus in vitro culture. Journal of Zhejiang University Agriculture and Life Science, 27(5), 527-530.

[18]. Wang, J. X., Sun, Y., Cui, G. M., Liu, S. X., Wang, G. P., Shang, Y. J. \& Wang, H. (2000). Effects of plant growth regulators and genotypes on the differentiation of in vitro cultured hypocotyls of rapeseed (Brassica). Chinese Journal of Oil Crop Sciences, 22(1), 11-13. 